\title{
Investigating Surface Water Pollution by Integrated Remotely Sensed and Field Spectral Measurement Data: A Case Study
}

\author{
Önder Gürsoy*, Rutkay Atun \\ Cumhuriyet University, Department of Geomatics Engineering, Sivas, Turkey
}

Received: 23 March 2018

Accepted: 26 April 2018

\begin{abstract}
Water quality assessment using remote sensing and its terrestrial components is carried out in short time for larger areas. Another issue that is as important regarding water availability is access to quality water. It is important to investigate the availability of the analysis of remotely sensed data instead of environmental and chemical analysis that determines water quality and usability. To examine the detection of water qualities without taking water samples in situ, spectral library data was used in the Hafik Region. In this context we used spectral measurement data of water samples previously taken from İmranl, where the Kizllırmak River originates, and used for spectral classification of water quality. Matched filtering was used for integrating spectral data and CHRIS Proba image as the spectral classification method. To conduct an accuracy analysis, chemical oxygen demand measurement was carried out at 10 points determined as 1 st and 2 nd water quality in the study area on the river and lakes according to the Ministry of the Environment and Urbanization. The overall accuracy of the classification was calculated as $70 \%$. The results of this study have shown the importance of spectral classification of satellite imagery in evaluating water quality and monitoring water resources.
\end{abstract}

Keywords: remote sensing, water quality, spectral measurements, matched filtering, CHRIS Proba

\section{Introduction}

Remote sensing technology and its terrestrial components are used for detecting environmental problems. One of the most important environmental problems in developing and developed countries is water pollution [1]. Water quality that was affected by water pollution is an important environmental factor [2]. The

*e-mail: ogursoy@cumhuriyet.edu.tr environmental factors affect people and their economic activities as well as concentrations of different water components, such as a waterbody, colored dissolved organic matter, chlorophyll, and total suspended solids. The water components can be measured and detected using satellite-based remote sensing [3, 4].

Although there are 16 river basins with a water popebtial of over 5 billion $\mathrm{m}^{3}$, such as Marmara, Susurluk, Batı Akdeniz, Antalya, Sakarya, Bat1 Karadeniz, Yeşilırmak, Doğu Akdeniz, Seyhan, Ceyhan, Firat, Doğu Karadeniz, Çoruh, Dicle, and Kizılırmak 
in Turkey, it is a major problem of pollution in water resources. Many contaminated elements were indicated in the Kizılırmak River Basin. For instance, Altınkaya and Derbent dams, which were built for energy, flood control, and irrigation purposes in the 1980s just south of the delta area, started to keep the alluviums brought by Kizilirmak, so the growth of the deltas stopped and even entered the process of shrinkage [5]. The downsizing of the delta has led to serious problems such as weakening of coastlines, damage to agricultural areas, and seawater filling the river bed. Using remote sensing and geographical information systems, it was observed that between 1987 and 2004, the Kizilirmak Delta landscape changed significantly due to non-natural causes. These can be summarized as the opening of drainage channels, the change of river bed, changes caused by dam construction, the expansion of settlements, and the increase of agricultural areas and the structures around them [6].

In remote sensing, many water quality studies have been carried out by examining criteria such as turbidity, the amount of suspended matter, chlorophyll content, temperature, and amounts of organic and inorganic substances [7-23].

The uses of hyperspectral images in water include flood detection and monitoring, detection of water quality, wetland mapping, measures of plant physiology and structure, and evapotranspiration. In studies using hyperspectral images, hyperspectral satellite images, or a plane-mounted sensor were used as data. Calibration data were provided by applying ground-based sampling of chlorophyll, suspended solids, turbidity, and water clarity. Then we made in situ measurements of the water. Models such as the analytical and numerical radiative transfer models were developed to determine water quality [24, 25].

The radiant water temperature was also measured by using a remote sensor, and the kinematic water temperature was measured by inserting a thermometer under the water. Ground-truth measurements were collected with thermal overflight at the same time. Thermal and visible imaging pairs for evaluation are sampled directly within the GIS environment. The physical quality of the stream is determined by water temperature [26].

In addition, evaluating water quality by remote sensing technology could be carried out by using different techniques. Models were created to assess water quality in these studies. The constructed model calculates water pollution by using data such as land use and fertilizer application rate [27].

In this study, it was hoped that the usability of integration of satellite image and spectral data, which was obtained from the spectral library, for detecting water quality and monitoring the water sources. For this purpose, the usability of the spectral classification method together with ground spectral measurements has been tested on high-resolution satellite images. As spectral data, measurements of water samples previously taken from the Imranlı region were used. Therefore, it has not been to collect water samples for use in water quality classification to Hafik. The matched filtering (MF) classification method has been used in this study since the MF has been successful in studies conducted in the İmranl1 region [28, 29]. In spectral classification, the ability to classify water quality by using spectral data in the database was tested without taking the water sample from the water surface. And then, for accuracy analysis, first and second quality water points were randomly selected according to the matched filtering result. The chemical oxygen demand (COD) values of the water samples taken from the water surface were measured at 10 points to evaluate the accuracy of the water quality classification.

\section{Study Area}

The Kizilırmak River is the longest potamic of Turkey, with a length of $1355 \mathrm{~km}$. The Kizilırmak originates and ends within Turkey. Kizilırmak water is drinkable at the source of the river but it decreases in quality along the flow direction and is not even used in agricultural irrigation in the Hafik region. There is also Yeniköy Stream, which feeds the Kizilırmak in the study area. And the lakes located in the region were included in the study area (Fig. 1). As mentioned above, due to the coexistence of the different qualities of water, Hafik Region was selected as the study area.

\section{Experimental}

\section{Materials}

In the scope of the study, high resolution satellite images from CHRIS Proba satellite image (CHRIS HA_150506_15A3_41) were obtained for free from the European Space Agency. CHRIS/PROBA offers single usability of recorded adjacent spectrum bands and provides high spatial resolution in the near infrared and visible spectral ranges [30]. CHRIS images are measured in 18 spectral bands in the range 415-1050 nm and have a spatial resolution of nearly $18 \mathrm{~m}$ (depending on viewing angle) and scanning (in mode 3) an area of about $15 \times 15 \mathrm{~km}$ at a maximum of five angles [3133]. In addition, ASD FieldSpec 4 Spectroradiometer measurement data were obtained from a previous study (İmranlı region) on water samples at a wavelength range between 350 and 2500 nanometres.

\section{Methods}

Image preprocessing steps are applied to satellite images. Radiometric and atmospheric correction of the images was performed using BeamVISAT software. The software was developed by Brockmann-Consult with support from ESA [34]. Then the geometric transformations of the images were made and the images 


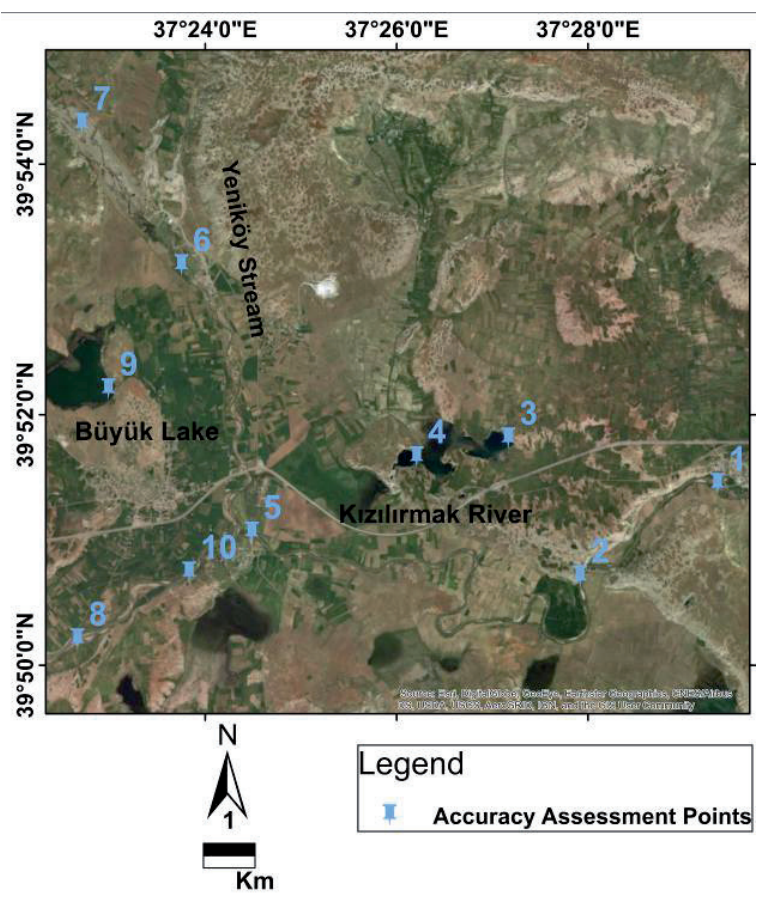

Fig. 1. Study area: Hafik region of the Kizılırmak River.

are defined in the $37^{\text {th }}$ region in the UTM projection system. Quality analyses of water samples were made on the basis of the Water Pollution Control Regulation of the Ministry of Environment and Urbanization [35].

Since the wavelength range of the spectroradiometer measurement data is between 350 and 2500 nanometers, Chris Proba cannot be directly classified into spectral classification with satellite image bands. This is why spectroradiometer data have been resampled (Fig. 2) to the 18 bands of Chris Proba (Table 1).

Matched filtering, a spectral classification method, is applied to satellite images for water quality classification. In Matched Filtering, reference data is classified according to abundance ratio of endmember content of $1^{\text {st }}$ and $2^{\text {nd }}$ quality water samples. The MF also

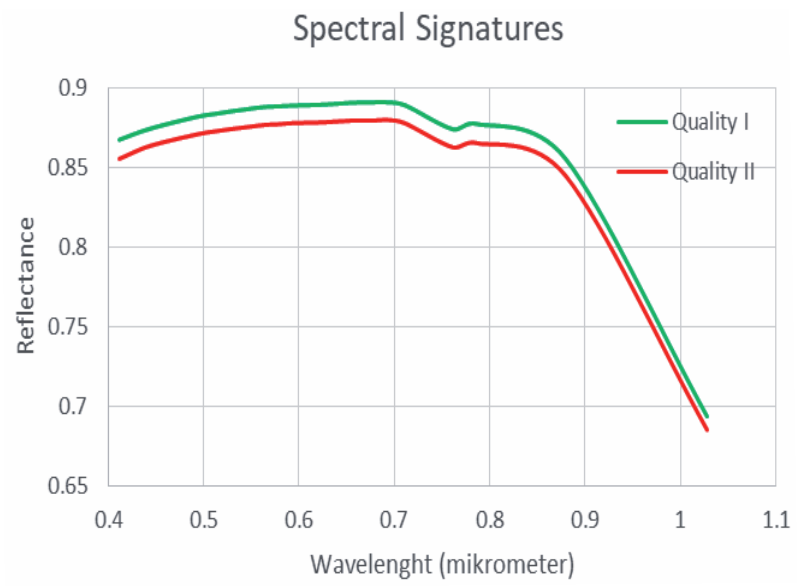

Fig. 2. Reflections of water qualities resampled to wavelength intervals of CHRIS Proba.
Table 1. Chris Proba bandwidth averages for resampling of spectroradiometer measurement data.

\begin{tabular}{|c|c|}
\hline CHRIS Proba Bands & Average Wavelength (NM) \\
\hline Radiance_1 & 411.5 \\
\hline Radiance_2 & 443.8 \\
\hline Radiance_3 & 492.1 \\
\hline Radiance_4 & 511.8 \\
\hline Radiance_5 & 532.3 \\
\hline Radiance_6 & 564.0 \\
\hline Radiance_7 & 576.5 \\
\hline Radiance_8 & 593.7 \\
\hline Radiance_9 & 625.8 \\
\hline Radiance_10 & 655.0 \\
\hline Radiance_11 & 673.5 \\
\hline Radiance_12 & 684.7 \\
\hline Radiance_13 & 693.3 \\
\hline Radiance_14 & 711.3 \\
\hline Radiance_15 & 761.3 \\
\hline Radiance_16 & 787.0 \\
\hline Radiance_17 & 879.7 \\
\hline Radiance_18 & 1028.0 \\
\hline
\end{tabular}

suppresses the information of the irrelevant reflections while maximizing the response of the reference endmembers [36].

\section{Results and Discussion}

In previous studies $[9,10,11,20,21,23]$, water quality researches were carried out based on terrestrial water sample measurements, band ratios, and models. But quality distribution on the water surface was not presented visually in those studies. In this study, the visualization of water quality via spectral classification was made in such a way that the spectral measurements of water samples were given chemical oxygen demand attribute data. Thus, quality classification can be made within the boundaries of the satellite image, not just the point-based but the entire water source.

Although some studies using remote sensing technology have used hyperspectral images, many studies have been done to visualize the spread of water quality $[14,18]$. Some studies used turbidity, dissolved oxygen, suspended solids, electrical conductivity, $\mathrm{pH}$, and depth in order to evaluate water quality $[8,15,16$, 19]. However, a spectral classification method was not used. In this study, in situ measurements and a spectral classification method were used in order to evaluate water quality, and different spectral classification 


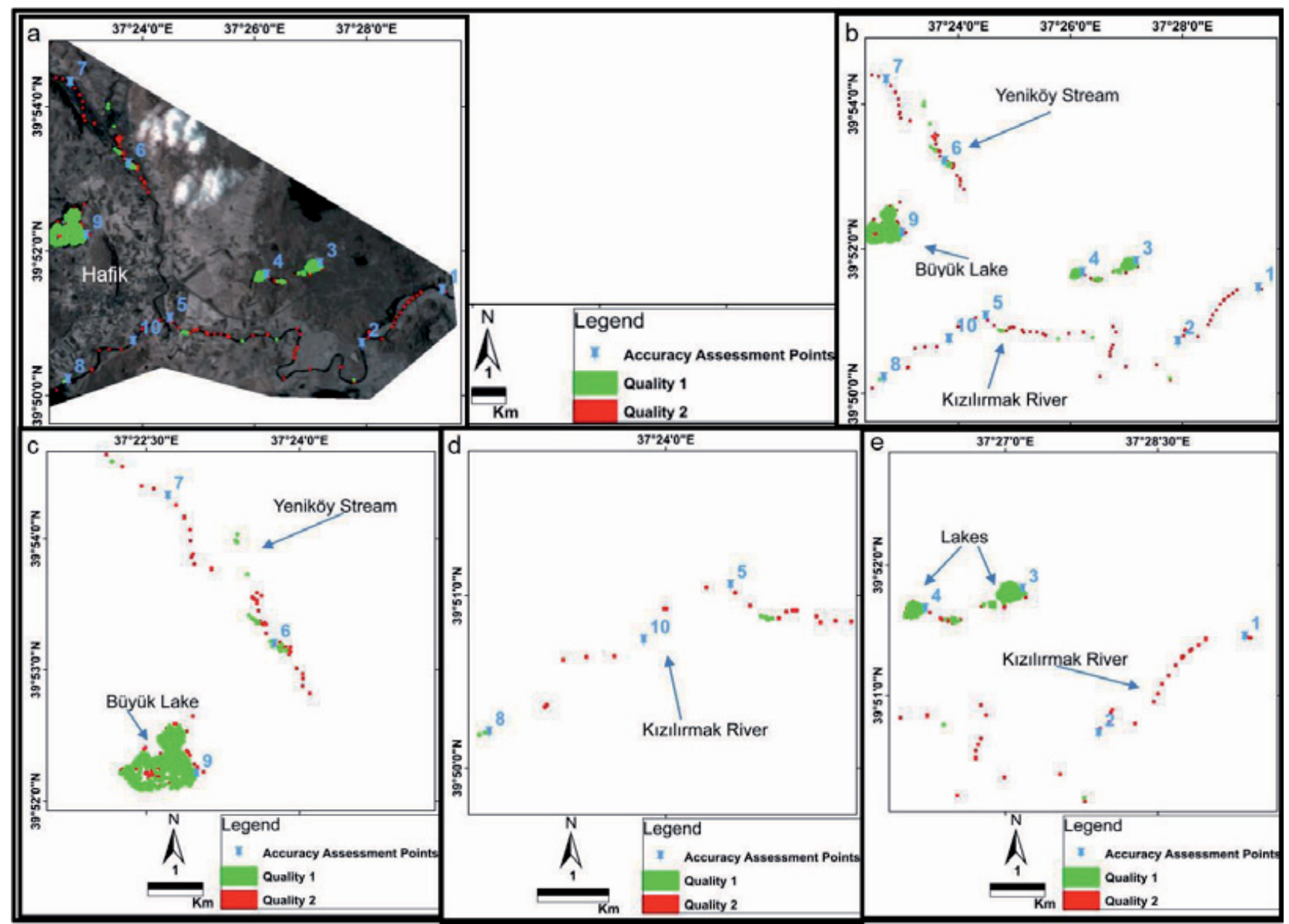

Fig. 3. MF results: a) Accuracy assessment points on basemap; b, c, d, e) Distrubution of MF results.

methods were tested by the authors without changing the endmember used in the previous spectral mapping $[27,28]$ to the east of the study area. Thus, water quality change along the direction of water flow was made.
According to the MF results in spectral classification, $1^{\text {st }}$ and $2^{\text {nd }}$ water quality classes were classified and visualized. According to the results obtained, it is understood that the water quality of Kiz1lirmak River

Table 2. Water quality evaluation parameters: the first column is related to the points used for accuracy assessment randomly, the second column deals with the measurements of the chemical oxygen demand of the water samples in situ, the third column shows the result of MF on the accuracy assessment points, and the last column refers to the quality of the water according to the COD in the catalogue of Ministry of Environment and Urbanization.

\begin{tabular}{|c|c|c|c|}
\hline $\begin{array}{c}\text { Accuracy Assessment } \\
\text { Points }\end{array}$ & COD & $\begin{array}{c}\text { Water Quality (Spectral Classification } \\
\text { Result) }\end{array}$ & $\begin{array}{c}\text { Water Quality (Ministry of the Environment } \\
\text { and Urbanization) }\end{array}$ \\
\hline 1 & 16.96 & Quality II & Quality II \\
\hline 2 & 19.52 & Quality I & Quality II \\
\hline 3 & 20.08 & Quality II & Quality II \\
\hline 4 & 16.32 & Quality II & Quality II \\
\hline 5 & 74.88 & Quality II & Quality II \\
\hline 6 & 12.8 & Quality I & Quality II \\
\hline 7 & 16.32 & Quality II & Quality I \\
\hline 8 & 4.36 & Quality I & Quality II \\
\hline 9 & 12.48 & Quality I & Quality II \\
\hline 10 & 10.24 & Quality II & \\
\hline
\end{tabular}


and Yeniköy Stream is generally of second-class quality and in Büyük Lake and other ponds it is of first-class quality (Fig. 3).

Because spatial resolution of the CHRIS Proba image used in the study is $17 \mathrm{~m}$, each pixel represents $289 \mathrm{~m}^{2}$ of area. Therefore, the spectral classification result of water quality is limited due to mixed pixels. The use of images with higher spatial resolution in spectra classification increases the classification accuracy.

The algorithm for spectral classification of satellite imagery in the study is pixel-based classification, which represents the entire pixel. The most important reason for the close proximity of the pixels with two different water qualities, especially on the accumulated water surface, is that the water penetration of optical satellite images is limited and in the blue wavelength range. This is due to the presence of floating bodies of water surface, which gives the second-class quality result.

For accuracy assessment, COD was made according to the Water Pollution Control Regulation of the Ministry of the Environment and Urbanization (Table 2). COD and spectral classification results are compared. The overall accuracy of classification was calculated as $70 \%$.

When the classification results are interpreted, it is understood that the quality analysis of water masses can be done by remote-sensing methods. It has been understood that the integration of hyperspectral remotesensing images and spectroradiometer data gives significant results in spectral classification.

\section{Conclusions}

The areas polluting the water source could be spotted using remote-sensing imagery along with its terrestrial measurement component. This study demonstrated the necessity of remote-sensing methods in detecting water quality. By using the spectral classification methods such as MF, a wide-range classification of water sources such as the Kizilırmak River could be made in a shorter time. Although the spectral resolution of CHRIS Proba satellite image is sufficient to detect water quality classes, the spatial resolution of the image is not sufficient to detect the quality variation in small areas. In this study, after the obtained MF classification result, 10 accuracy assessment points were selected randomly on the result to measure $\mathrm{COD}$ in situ at the points. In terms of increasing the number of random points, it could be possible to obtain higher overall accuracy.

The result will also form the basis for future studies and may be applied to other regions after water content analysis. It is possible to determine the water participation areas on the water supply which have a negative effect on water quality. The use of satellite images with higher spatial and spectral resolutions such as a hyperspectral airborne system could be able to assess water content as well as water quality change.

\section{Acknowledgements}

We want to thank CUBAP (Cumhuriyet University Scientific Research Projects) for M - 614 numbered project data and their co-operation. We extend our gratitude to Assoc. Prof. Dr. Fuat Özyonar, Res. Assistant Anıl Can Birdal, and Assist. Prof. Dr. Ergun Kasaka for their contributions.

\section{Conflict of Interest}

The authors declare no conflict of interest.

\section{References}

1. REVOR D., CASTON M., ZWELABO S. An assessment of the effect of industrial and sewage effluent on aquatic invertebrates: a case study of a southern urban stream, Zimbabwe. Journal of Sustainable Development, 3 (2), 210, 2010.

2. HE W., CHEN S., LIU X., CHEN J. Water quality monitoring in a slightly polluted inland water body through remote sensing: case study of the Guanting Reservoir in Beijing, China. Front Environ. Sci. Eng. China 2 (2), 163, 2008.

3. HU C., LEE Z., MA R., YU KL., SHANG S. Moderate resolution imaging spectroradiometer (MODIS) observations of cyanobacteria blooms in Taihu Lake, China. Journal of Geophysical Research, 115, 1, 2010.

4. KAYA Ş., KUTUKCU A. Investigation of morphometric and hydrological characteristics of a water basin using numerical models. Fresenius Environmental Bulletin, 26 (1), 360, 2017.

5. YILMAZ C. Geographic analysis of erosion in Kizilirmak delta. Turkey Quaternary Symposium. ITU Eurasia Institute of Earth Sciences: Istanbul, Turkey, 5, 96, 2005.

6. SERTEL E., FINDIK N., KAYA Ş., ŞEKER D.Z., SAMSUNLU A. Assessment of landscape changes in the Kizilirmak Delta, Turkey, Using Remotely Sensed Data and GIS. Environmental Engineering Science, 25 (3), 353, 2008.

7. GIARDINO C., CANDIANI G., BRESCIANI M., LEE Z., GAGLIANO S., PEPE M. BOMBER: A tool for estimating water quality and bottom properties from remote sensing images. Computers and Geosciences, 45, 313, 2012.

8. WU Z., ZHANG J., ZHU J., RE J., CHEN S. A monitoring project planning technique of the water quality spatial distribution in Nansi lake. Procedia Environmental Sciences, 10 (C), 2320, 2011.

9. URBANSKI A., WOCHNA J. BUBAK A., GRZYBOWSKI I., MATUSZEWSKA W.L., ŁAZCKA K., ŚLIWIŃSKA M., WOJTASIEWICZ B., ZAJĄCZKOWSKI B. Application of Landsat 8 imagery to regional-scale assessment of lake water quality. International Journal of Applied Earth Observation and Geoinformation, 51, 28, 2016.

10. DLAMINI S., NHAPI I., GUMINDOGA W., NHIWATIWA T., DUBE T. Assessing the feasibility of integrating remote sensing and in-situ measurements in monitoring water quality status of Lake Chivero, 
Zimbabwe. Physics and Chemistry of the Earth, 93, 2, 2016.

11. CHAWIRA M., DUBE T., GUMINDOGA W. Remote sensing based water quality monitoring in Chivero and Manyame lakes of Zimbabwe. Physics and Chemistry of the Earth, 66, 38, 2013.

12. ZHOU Z., ZHAO Y. Research on the water quality monitoring system for inland lakes based on remote sensing. Procedia Environmental Sciences, 10 (B), 1707, 2011.

13. UMAR M., RHOADS B.L., GREENBERG J.A. Use of multispectral satellite remote sensing to assess mixing of suspended sediment downstream of large river confluences. Journal of Hydrology, 556, 325, 2018.

14. KAYA Ş., ŞEKER D.Z., TANIK A. Temporal impact of urbanization on the protection zones of two drinking water reservoirs in Istanbul. Fresenius Environmental Bulletin, 23 (12), 2984, 2014.

15. ISPRS Journal of Photogrammetry and Remote Sensing, 66 (4), 436, 2011.

16. MARQUEZ L.C.G., BEJARANO F.M.T., ESPINOZA A.C.T., RODRÍGUEZ I.R.H. Use of LANDSAT 8 images for depth and water quality assessment of El Guájaro reservoir, Colombia. Journal of South American Earth Sciences, 82, 231, 2018.

17. MASOCHA M., MURWIRA A., MAGADZA C.H.D., HIRJI R., DUBE T. Remote sensing of surface water quality in relation to catchment condition in Zimbabwe. Physics and Chemistry of the Earth, 100, 13, 2017.

18. OLMANSON L.G., BREZONIK P.L., FINLAY J.C., BAUER M.E. Comparison of Landsat 8 and Landsat 7 for regional measurements of CDOM and water clarity in lakes. Remote Sensing of Environment, 185, 119, 2016.

19. ROSTOM N.G., SHALABY A.A., ISSA Y.M., AFIFI A.A. Evaluation of Mariut Lake water quality using Hyperspectral Remote Sensing and laboratory works. The Egyptian Journal of Remote Sensing and Space Science, 20, 39, 2017.

20. KİEFER I., ODERMATT D., ANNEVILLE O., WÜEST A., BOUFFARD D. Application of remote sensing for the optimization of in-situ sampling for monitoring of phytoplankton abundance in a large lake. Science of the Total Environment, 527-527, 493, 2015.

21. DÖRNHÖFER K., OPPELT N. Remote sensing for lake research and monitoring - Recent advances. Ecological Indicators, 64, 105, 2016.

22. LOTFINASABASL S., GUNALE V.R., KHOSROSHAHI M. Applying geographic information systems and remote sensing for water quality assessment of mangrove forest. Acta Ecologica Sinica, 38, 135, 2018.

23. KİM H.C., SON S., KIM Y.H., KHIM J.S., NAM J., CHANG W.K., LEE J.H., LEE C. H., RYU J. Remote sensing and water quality indicators in the Korean West coast: Spatio-temporal structures of MODIS-derived chlorophyll-a and total suspended solids. Marine Pollution Bulletin, 121 (1-2), 425, 2017.

24. OLMANSON L.G., BREZONIK P.L., BAUER M.E. Airborne hyperspectral remote sensing to assess spatial distribution of water quality characteristics in large rivers:
The Mississippi River and its tributaries in Minnesota. Remote Sensing of Environment, 130, 254, 2013.

25. KAYA Ş., BAŞAR U.G., KARACA M., ŞEKER D.Z. Assessment of urban heat islands using remotely sensed data. Ekoloji, 21 (84), 107, 2012.

26. TORGERSEN C.E., FAUX R.N., MCINTOSH B.A., POAGE N.J., NORTON D.J. Airborne thermal remote sensing for water temperature assessment in rivers and streams. Remote Sensing of Environment, 76 (3), 386, 2001.

27. MATTIKALLİ N.M., RICHARDS K.S. Estimation of surface water quality changes in response to land use change: Application of the export coefficient model using remote sensing and geographical information system. Journal of Environmental Management, 48 (3), 263, 1996.

28. GÜRSOY Ö. Determining the Most Appropriate Classification Methods for Water Quality. IOP Conference Series Earth and Environmental Science 44 (2), doi:10.1088/1755-1315/44/2/022038, 2016.

29. GÜRSOY Ö., BİRDAL A.C., ÖZYONAR F., KASAKA E. Determining and Monitoring the Water Quality of Kizilirmak River of Turkey: First Results. 36th International Symposium on Remote Sensing of Environment, 11-15 May 2015, Berlin, Germany.

30. GUANTER L., ALONSO L., MORENO J. First results from the PROBA/CHRIS hyperspectral/multiangular satellite system over land and water targets. IEEE Geoscience and Remote Sensing Letters, 2 (3), 250, 2005.

31. RAUTIAINEN M., LANG M., MÕTTUS M., KUUSK A., NILSON T., KUUSK J., LÜKK T. Multi-angular reflectance properties of a hemiboreal forest: An analysis using CHRIS PROBA data. Remote Sensing of Environment, 112 (5), 2627, 2008.

32. CHAN WAI J.C., BECKERS P., SPANHOVE T., VANDEN BORRE J. An evaluation of ensemble classifiers for mapping Natura 2000 heathland in Belgium using spaceborne angular hyperspectral (CHRIS/Proba) imagery. International Journal of Applied Earth Observation and Geoinformation, 18 (1), 13, 2012.

33. DEMARCHİ L., CHAN J.C.W., MA J., CANTERS F. Mapping impervious surfaces from superresolution enhanced CHRIS/Proba imagery using multiple endmember unmixing. ISPRS Journal of Photogrammetry and Remote Sensing, 72, 99, 2012.

34. MILLÁN V.E.G., SANCHEZ-AZOFEIFA G.A., MALVÁREZ G.C. Mapping Tropical Dry Forest Succession With CHRIS/PROBA Hyperspectral Images Using Nonparametric Decision Trees. IEEE Journal of Selected Topics in Applied Earth Observations and Remote Sensing, 8 (6), 3081, 2015.

35. Republic of Turkey, Ministry of Environment and Urbanization, Laws on Management of Water Pollution www.csb.gov.tr/db/cygm/editordosya/YON-25687SKKY. docx URL (accessed on 15.02.2014)

36. GÜRSOY Ö., CANBAZ O., GÖKÇE A., ATUN R. Spectral Classification in Lithological Mapping; A Case Study of Matched Filtering. Cumhuriyet Sci., 38 (4), 731, 2017. 